\title{
PENYULUHAN MASTITIS SUBKLINIS PADA SAPI PERAH DI DESA MEKAR BAKTI KECAMATAN PAMULIHAN KABUPATEN SUMEDANG JAWA BARAT
}

\author{
Sarasati Windria, Hesti Lina Wiraswati, Julia Ramadhanti, Trianing tyas K.A, dan Okta Wismandanu \\ Pusat Studi Infeksi, Fakultas Kedokteran, Universitas Padjadjaran, Bandung, Indonesia \\ E-mail: sarasati.windria@unpad.ac.id
}

\begin{abstract}
ABSTRAK. Mastitis subklinis merupakan radang ambing yang sering menyerang hewan ternak khususnya ternak penghasil susu. Dampak kerugian mastitis subklinis cukup besar diantaranya penurunan kuantitas dan kualitas susu secara drastis, namun tidak ditemukan adanya perubahan patologis pada sapi. Desa Mekar Bakti yang terletak di Kecamatan Pamulihan, Kabupaten Sumedang Jawa Barat merupakan salah satu desa yang menjadi sentra penghasil susu di Wilayah Sumedang. Tingginya angka kejadian mastitis subklinis mendorong untuk dilakukan penyuluhan mengenai mastitis subklinis. Kegiatan penyuluhan dilakukan dengan cara pemaparan materi tentang mastitis subklinis dengan teknik ceramah (slide powerpoint), video serta tanya jawab. Selain itu, upaya peningkatan hasil peternakan dilakukan dengan memberi penyuluhan teknik pembuatan "Pupuk Intensifikasi Tahi Sapi Organik Cair" (PITSA OC) dan pelatihan pembuatan susu sapi pasteurisasi. Rangkaian kegiatan penyuluhan ini sebagai upaya untuk menekan angka kejadian mastitis subklinis melalui peningkatan pemahaman masyarakat.
\end{abstract}

Kata kunci: mastitis, mastitis subklinis, sapi perah, penyuluhan

\begin{abstract}
Subclinical mastitis is an inflammation of the udder that often attacks livestock, especially milk-producing livestock. The impact of the loss of subclinical mastitis is quite large, including a dramatic decrease in the quantity and quality of milk, but no pathological changes in cattle have been found. Mekar Bakti Village, located in Pamulihan Subdistrict, Sumedang Regency, West Java, is one of the villages that is the center for producing milk in the Sumedang Region. The high incidence of subclinical mastitis encourages counseling regarding subclinical mastitis. Promotion activities were carried out by presenting material about subclinical mastitis with lecture techniques (power point slides), videos and discussion. In addition, efforts to increase livestock yields were carried out by giving information on the technique of making "Liquid Organic Cattle Fertilizer Intensification" (PITSA OC) and training in making pasteurized cow milk. This series of counseling activities is an effort to reduce the incidence of subclinical mastitis through increasing community knowledge.
\end{abstract}

Key words: mastitis,mastitis subklinis, cows, counseling

\section{PENDAHULUAN}

Mastitis atau radang ambing sering menyerang sapi-sapi perah baik milik perusahaan maupun sapi perah milik peternak kecil yang banyak menimbulkan kerugian. Kejadian mastitis pada sapi perah di Indonesia sangat tinggi yaitu mencapai $85 \%$, dan kejadian ini sebagian besar merupakan infeksi subklinis sehingga tidak cepat dilakukan penanganan ataupun pengendalian. Akibat dari kejadian mastitis ini dapat menyebabkan kerugian ekonomi yang cukup besar terutama karena turunnya produksi susu yang dapat mencapai $25 \%$ dari total produksi (Sudarwanto et al., 2006).

Berdasarkan gejala klinis, mastitis dikelompokkan menjadi dua yaitu mastitis klinis dan subklinis. Mastitis klinis menampakkan gejala klinis seperti pembengkakan, meningkatnya suhu tubuh dan frekuensi nafas, nafsu makan turun yang disertai dengan perubahan komposisi air susu maupun bentuk ambing. Mastitis subklinis ditandai dengan peningkatan jumlah sel somatik dalam susu tanpa disertai pembengkakan ambing, dan jika diuji dengan menggunakan California mastitis test (CMT) maka terjadi koagulasi pada susu yang diuji (Marogna et al., 2012). California Mastitis Test (CMT) adalah uji yang menggunakan prinsip penambahan reagen serupa dengan detergen pada sampel susu, Interpretasi hasil uji CMT diklasifikasikan ke dalam 4 kategori, yaitu negatif, trace, positif $1(+1)$, positif $2(+2)$ dan positif $3(+3)$ (Shearer dan Harris, 2003; Setiawan et al., 2013).

Kecamatan Pamulihan yang terletak di Kabupaten Sumedang termasuk sentra produksi susu sapi di wilayah Jawa Barat dan memegang peranan dalam pemenuhan kebutuhan susu setelah Lembang. Koperasi Serba Usaha (KSU) "Tandangsari" merupakan koperasi yang menampung hasil susu sapi perah dari peternakan peternakan rakyat yang ada di Wilayah Tanjungsari dan Pamulihan memiliki data bahwa angka kejadian mastitis pada tahun 2018 tercatat sebesar 40\%. Data awal yang diperoleh mendorong dilakukan penelitian dan pendataan mengenai kasus mastitis serta dilakukan penyuluhan dengan harapan memberikan sosialisai masyarakat peternak, sehingga diharapkan dapat menekan angka kerugian yang timbul akibat kasus mastitis.

\section{METODE}

Metode yang digunakan untuk mengetahui angka kejadian mastitis subklinis di kelompok "Putra Saluyu" adalah dengan menyebar angket kuisioner pada seluruh anggota yaitu sebanyak 50 orang. Angket kuisioner berisikan tentang pertanyaan yang mengenai: 1.) Pemahaman masyarakat mengenai pemahaman terhadap definisi umum mastitis, 2.) Definisi mastitis subklinis dan 3.) Gejala yang timbul pada kasus mastitis subklinis. Data 
hasil angket kuisioner menjadi dasar untuk pemilihan materi yang disampaikan ketika penyuluhan dan sosialisasi pada kelompok ternak.

Metode sosialisasi yang digunakan untuk penyuluhan adalah menggunakan alat peraga berupa slide power point yang berisikan materi umum, video mengenai metode deteksi dini mastitis subklinis menggunakan California Mastitis Test (CMT) serta tanya jawab seputar materi yang telah disampaikan sebagai indikator keberhasilan penyuluhan.

\section{HASIL DAN PEMBAHASAN}

Desa Mekar bakti merupakan sebuah desa yang berada di wilayah Kecamatan Pamulihan Kabupaten Sumedang. Lokasinya berada di ujung barat daya wilayah kecamatan dan berbatasan langsung dengan dua kecamatan yaitu Kecamatan Tanjungsari dan Kecamatan Cimanggung. Data Badan Pusat Statistik (BPS) tahun 2016-2017 mencatat status desa sebagai pedesaan dengan klasifikasi desa swadaya lanjut, memiliki luas daerah 409,6 Ha (Sawah 16,0 Ha; ladang 211,6 Ha dan rumah pekarangan 181,7 Ha), melihat dari tata guna lahan yang sebagian besar digunakan sebagai lahan persawahan dan dan ladang maka sebagian besar penduduk desa Mekarbakti bekerja di sektor pertanian dan peternakan khususnya sapi perah. Area desa Mekarbakti dapat dilihat pada Gambar 1.

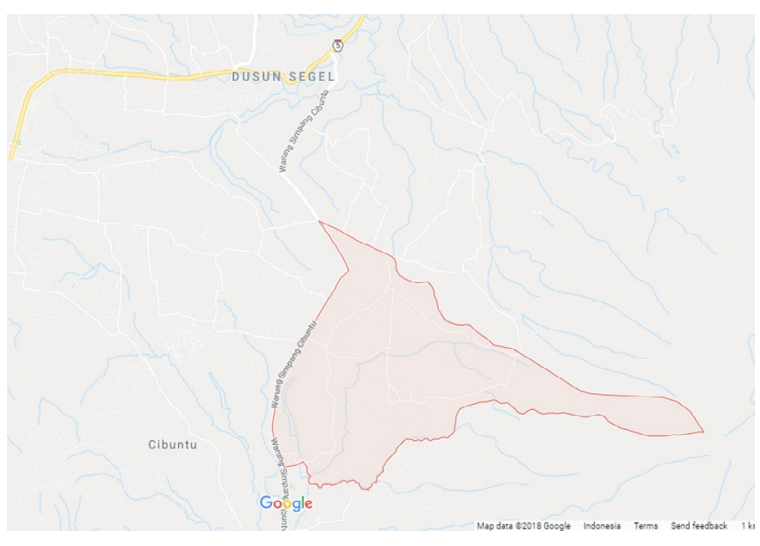

(Sumber : Google maps, 2018)

Gambar 1. Area Desa Mekarbakti, Kecamatan Pamulihan Kabupaten Sumedang, Jawa Barat

Kelompok ternak "Putra Saluyu" beranggotakan 50 orang yang masing-masing anggota memiliki sapi perah sebanyak $\pm 7-15$ ekor. Data hasil angket kuisioner menunjukkan bahwa responsibilitas masyakarat sebesar $70 \%$, angka tersebut dapat disimpulkan dari jumlah angket kuisioner yang kembali dan dapat didata berasal dari 35 orang. Jumlah anggota yang paham mengenai definisi secara umum mastitis sebanyak 30 orang atau sebesar $85,7 \%$ sedangkan 5 orang atau sebesar $14,3 \%$ tidak paham sama sekali mengenai mastitis. Definisi mastitis secara umum merupakan mastitis klinis, yaitu mstitis yang timbul disertai dengan adanya gejala klinis diantaranya bengkak, keras kemerahan, bahkan terdapat luka pada ambing sapi. Akan tetapi, berdasarkan data angket kuisioner jumlah anggota yang paham mengenai mastitis subklinis dan gejala yang timbul hanya sebanyak 2 orang atau sebesar 5,7\%. Gambar lengkap mengenai hasil angket kuisioner disajikan pada gambar 2 .

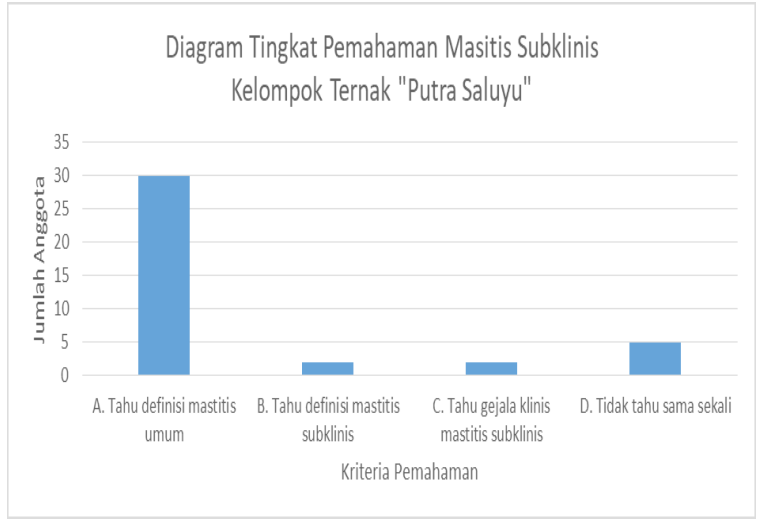

Gambar 2. Diagram Tingkat Pemahaman Mastitis Subklinis Kelompok Ternak "Putra Saluyu" (Sebelum Penyuluhan)

Hasil surveillance di Wilayah "Mekar Bakti" mendorong untuk dilakakukan penyuluhan pada masyarakat yang merupakan salah satu bentuk pengabdian kepada masyarakat. Penyuluhan yang diberikan pada anggota kelompok ternak "Putra Saluyu" dengan topik seputar mastitis meliputi pengertian mastitis, jenis-jenis mastitis, gejala klinis yang ditimbulkan baik pada mastistis klinis dan subklinis, metode deteksi mastitis subklinis menggunakan California Mastitis Test (CMT), cara pengobatan dan alternatif serta cara pencegahannya. Selain penyuluhan mengenai mastitis juga diberikan penyuluhan mengenai cara pembuatan "Pupuk Intensifikasi Tahi Sapi Organik Cair" (PITSA OC) dan pelatihan pembuatan susu sapi pasteurisasi. Penyuluhan pembuatan "PITSA OC" dan susu sapi pasteurisasi yang diberikan oleh mahasiswa KKN sebagai usaha untuk meningkatkan nilai tambah perekonomian masyarakat Desa Mekar Bakti khususnya sektor peternakan sapi perah (Gambar 3.)

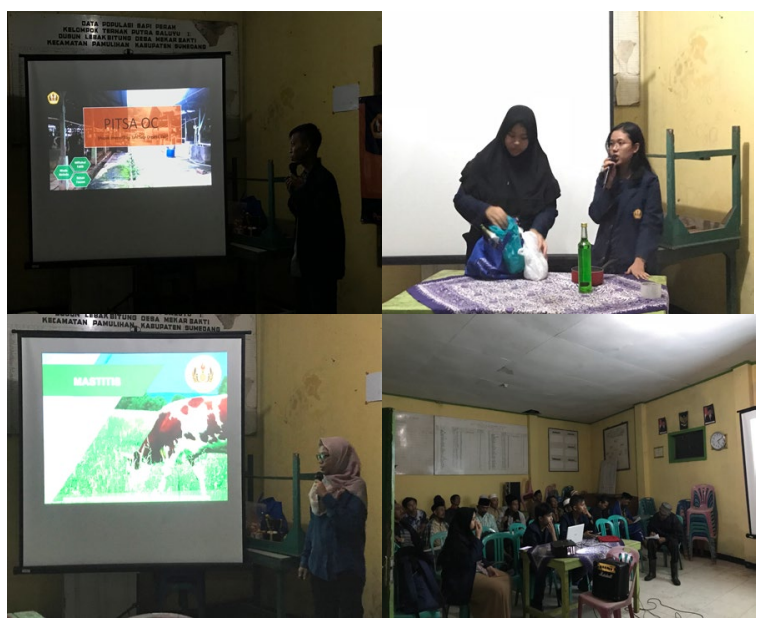

Gambar 3. Rangkaian Kegiatan Penyuluhan Mastitis Subklinis di Kelompok Ternak "Putra Saluyu" 
Keberhasilan penyuluhan ini ditandai dengan antusias dan ketepatan peserta penyuluhan dalam menjawab pertanyaan yang diberikan setelah pemaparan materi. serKeterlibatan mahasiswa KKN Unpad 2018 sebagai sarana interaksi langsung antara mahasiswa kepada masyarakat. Observasi lingkungan serta interaksi langsung dengan masyarakat mendorong mahasiswa untuk dapat memberikan ilmu yang telah dipelajari, serta mengetahui kondisi real di lapangan tentang fakta apa saja yang terjadi dibutuhkan masyarakat sesuai dengan bidang keilmuan masing-masing. Hasil dari observasi, interaksi dan penyuluhan dapat dijadikan bekal mahasiswa untuk meningkatkan Ilmu Pengetahuan dan Teknologi (IPTEk).

\section{SIMPULAN}

Penyuluhan mengenai mastitis subklinis di Kelompok ternak "Putra Saluyu", Desa Mekar Bakti, Kecamatan Pamulihan, Kabupaten Sumedang Jawa Barat bejalan dengan lancar. Dampak dari penyuluhan ini adalah menambah pemahaman masyarakat bahwa terdapat tipe mastitis yang terjadi tanpa disertai gejala klinis sehingga dapat diantisipasi dengan cara pemeriksaan dini menggunakan metode screning California Mastitis Test (CMT) dengan demikian diharapkan dapat menekan angka kerugian ekonomi yang muncul sebagai dampak kasus mastitis subklinis ini.

\section{UCAPAN TERIMA KASIH}

Ucapan terimakasih penulis sampaikan kepada Direktorat Riset, Pengabdian Kepada Masyarakat, dan Inovasi
(DRPMI) Universitas Padjadjaran yang telah mendanai penelitian ini sehingga bisa berjalan dengan baik. Ucapan terima kasih juga penulis sampaikan kepada KSU "Tandangsari" dan kelompok ternak "Putra Saluyu" yang telah menjadi mitra dalam pelaksanaan penelitian ini.

\section{DAFTAR PUSTAKA}

Marogna G., Rolesu S., Lollai S., Tola S., Leori G. 2010. Clinical findings in sheep farms affected by recurrent bacterial mastitis. Small Ruminant Research 88, 119-125.

Marogna G., Pilo C., Vidili A., Tola S., Schianchi G., Leori S.G. 2012. Comparison of clinical findings, microbiological results, and farming parameters in goat herds affected by recurrent infectious mastitis. Small Ruminant Research 102, 74-83.

Sudarwanto, M., Latif, H. and Noordin, M. 2006, July. The relationship of the somatic cell counting to sub-clinical mastitis and to improve milk quality. In 1st International AAVS Scientific Conference. Jakarta.

Setiawan, J., Maheswari, R.R.A., dan Purwanto, B.P. 2013. Sifat Fisik dan Kimia, Jumlah Sel Somatik dan Kualitas Mikrobiologis Susu Kambing Peranakan Ettawa. ACTA veterinaria indonesiana-indonesian veterinary journal 1(1), 32-43.

Shearer J.K and Harris Jr.B. 2003. Mastitis in dairy goats. IFAS Extension. University of Florida. USA 